J. Med. Microbiol. — Vol. 46 (1997), 67-74

(C) 1997 The Pathological Society of Great Britain and Ireland

\title{
Surface properties of diarrhoeagenic Escherichia coli isolates
}

\author{
J. N. FLETCHER* $\dagger$, J. R. SAUNDERS*, H. EMBAYE $\ddagger$ R. M. ODEDRA $\ddagger$, R. M. BATT $\ddagger$ and \\ C. A. HART†
}

Departments of * Genetics and Microbiology and †Medical Microbiology, University of Liverpool, PO Box 147 , Liverpool L69 3BX and $\ddagger$ Department of Small Animal Medicine and Surgery, Royal Veterinary College, University of London, North Mymms, Hatfield, Herts AL9 7TA

\begin{abstract}
The surface properties of various Escherichia coli isolates associated with diarrhoeal illness were compared by aqueous partitioning between polyethylene glycol (PEG) and Dextran phases. Two well characterised strains of enteropathogenic $E$. coli (EPEC) were found to be very hydrophobic, based on the critical polymer concentration. EPEC strain E2348 cured of the EPEC adherence factor (EAF) plasmid had much reduced surface hydrophobicity. Partitioning of a series of diarrhoeagenic $E$. coli strains demonstrated that the majority of $\mathrm{EAF}^{+}$EPEC strains were significantly more hydrophobic than EAF $^{-}$EPEC strains. $E$. coli strains defined as enteroaggregative on the basis of hybridisation with a specific DNA probe showed much greater heterogeneity in their partitioning behaviour, possibly indicating that the AAF/I pili were not expressed in all strains. The $E$. coli K-12 strain used as a transformation host for adhesion studies had very low surface hydrophobicity but had a detectable negative charge. No alteration in these properties was observed when transformed with EPEC and recombinant plasmids known to specify adherence to tissue culture cells.
\end{abstract}

\section{Introduction}

A vital step in the early stages of infection by many bacterial pathogens is the initial adherence to the mucosal surfaces of respiratory, gastrointestinal or urinary tract epithelium, and in some instances colonisation alone may be sufficient to cause disease [1]. In certain cases, specific adhesins, such as the P fimbriae of many strains of $E$. coli associated with urinary tract infections have been shown to be responsible for binding to specific receptors expressed on the surface of epithelial cells [2]. Bacterial binding may also be promoted by non-specific physical properties of the cells. Surface properties such as charge and hydrophobicity have been associated with the ability of a wide variety of bacteria to adhere to non-biological materials [3]. More specifically, surface hydrophobicity has been shown to promote adhesion of E. coli, Salmonella typhimurium and Neisseria gonorrhoeae to HeLa cells [4], group B streptococci to buccal epithelial cells [5]

Received 8 March 1996; revised version accepted 24 June 1996.

Corresponding author: Dr J. N. Fletcher.

Present address: Department of Biomedical Sciences, University of Bradford, Bradford, W. Yorkshire BD7 1DP. and Staphylococcus epidermidis to coated and uncoated plastic catheters [6], and to be positively correlated to virulence in Shigella spp. [7]. The expression of adhesins may in itself cause changes in surface hydrophobicity. For example, in Yersinia enterocolitica, the presence of the virulence plasmid pYV results in an increased ability to adhere to ileal brush border vesicles, along with an increase in surface hydrophobicity, due to the expression of the plasmid-encoded fibronectinbinding protein YadA $[8,9]$.

Adherence of enteropathogenic E. coli (EPEC) to the small intestinal epithelium is a prelude to the generation of the characteristic attaching-effacing lesions $[10,11]$. Adhesion of EPEC to tissue culture cells has been studied extensively, resulting in the identification of EPEC adherence factor (EAF) plasmids associated with the formation of bacterial microcolonies by the phenomenon termed localised adherence [12,13]. The adhesin responsible is believed to be an inducible bundle-forming pilus, the structural protein of which is encoded by the $b f p A$ gene carried on the EAF plasmid $[14,15]$, and which is related to the type IV fimbriae of several other pathogenic micro-organisms. A second EPEC virulence gene has been identified, the chromosomally located eaeA. This 
encodes intimin, a $94-\mathrm{kDa}$ outer-membrane protein with significant homology to the integrin-binding invasion proteins of $Y$. enterocolitica and $Y$. pseudotuberculosis $[16,17]$.

Whilst the EAF-associated adhesins have a role in virulence, there is incontrovertible evidence that EPEC strains lacking EAF sequences are also able to cause diarrhoeal illness, but generally with decreased virulence $[18,19]$. By implication such EPEC strains must be able to adhere to the intestinal epithelium. In previous studies, E. coli $\mathrm{K}-12$ tranformants were described that carried plasmids from an EPEC strain, one of which, DH1(pLV501), had a localised adherence phenotype but did not carry EAF sequences. It was also capable of adhering to and effacing the microvilli of the brush border in a rabbit ileal explant model [20]. A recombinant plasmid derived from pLV501 has been shown to carry a novel invasive determinant, and also encodes the ability to adhere to HEp-2 cells, albeit in a diffuse fashion [21]. No specific adhesins have been identified to account for the properties of these transformants.

In this study, aqueous two-phase partitioning was used to measure the cell surface hydrophobicity of a series of EPEC and related strains in order to investigate the relationship between hydrophobicity and EAF carriage, and also to analyse the possible role of surface properties in the adhesive transformants.

\section{Materials and methods}

\section{Bacterial strains}

The E. coli clinical isolates used in this study are listed in Table 1 [20-25]. The original sources of the majority have been described previously [21]. However, certain strains therein identified as EPEC (C727, D103, D163, D176, B/M 369 and C-35) have subsequently been reclassified as enteroaggregative $E$. coli (EAggEC).
Further E. coli strains used were H311B and ST/W [24], supplied by courtesy of Dr R. Robins-Browne, University of Melbourne; E2348 [22] and its plasmid-cured derivative MAR20 [23] supplied by $\mathrm{Dr}$ M. Levine, Center for Vaccine Development, Baltimore, USA; D5981 and D6211, isolated from colonic biopsy samples from a patient suffering from inflammatory bowel disease, supplied by Dr $\AA$. Ljungh, University of Lund. Strains 9/0992, 123/0992 and 171/1092 were from dogs with severe diarrhoeal disease, and D914 from a cat with a similar illness. Transformants DH1(pLV501) and DH1(pLV527) have been described previously [20, 21]. Transformant DH1(pLV526) carries a recombinant plasmid containing $15-\mathrm{kb}$ of pLV501 DNA inserted into the EcoRI/Sal I sites of pBR322: no phenotypic effect on tissue culture cells or rabbit ileal explants has been observed with this transformant. Other enteropathogenic, enteroaggregative and enteroinvasive strains were from the culture collection of the Department of Medical Microbiology, University of Liverpool.

Bacteria were grown in liquid culture in $\mathrm{Lab} \mathrm{M}$ Nutrient Broth (Amersham) $2.5 \% \mathrm{w} / \mathrm{v}$ at $37^{\circ} \mathrm{C}$ with continuous shaking, with appropriate antibiotic selection for those strains containing recombinant plasmids. Strains were stored in nutrient broth containing glycerol $10 \% \mathrm{v} / \mathrm{v}$ at $-70^{\circ} \mathrm{C}$.

\section{Serogrouping}

Confirmation of bacterial serogroup was by slide agglutination with specific antisera according to the manufacturer's instructions (Wellcome, Beckenham).

\section{Probing}

Bacterial colonies immobilised on to Hybond $\mathrm{N}$ membrane (Amersham) were hybridised to specific probes for EAF [26] and eaeA [27]. Enteroaggregative E. coli strains were confirmed by hybridisation with a specific EAgg probe [28]. Probe restriction fragments

Table 1. E. coli clinical strains used for phase partitioning studies

\begin{tabular}{|c|c|c|c|}
\hline Strain no. & Source & Relevant genotype & Reference no. \\
\hline E2348 & Infant diarrhoea & $\mathrm{eaeA}^{+}, \mathrm{EAF}^{+}$ & 22 \\
\hline K798 & Infant diarrhoea & $\mathrm{eaeA}^{+}, \mathrm{EAF}^{+}$ & 20 \\
\hline $\begin{array}{l}\text { D46; D48; D50; D51; D53; } \\
\quad \text { D55; E380/69; E851/71; E16501 }\end{array}$ & Infant diarrhoea & $e a e A^{+}, \mathrm{EAF}^{+}$ & 21 \\
\hline $\mathrm{ST} / \mathrm{W}$ & Infant diarrhoea & $e a e A^{+}, \mathrm{EAF}^{+}$ & 24 \\
\hline D23; D24; D96; D162 & Infant diarrhoea & $e a e A^{+}, \mathrm{EAF}^{-}$ & 21 \\
\hline $\mathrm{H} 311 \mathrm{~B}$ & Infant diarrhoea & $e a e A^{+}, \mathrm{EAF}^{-}$ & 24 \\
\hline RDEC-1 & Rabbit with diarrhoea & $e a e A^{+}, \mathrm{EAF}^{-}$ & 25 \\
\hline $\mathrm{C} 408 ; \mathrm{C} 412$ & Calves with diarrhoea & $e a e A^{+}, \mathrm{EAF}^{-}$ & 21 \\
\hline $9 / 0992 ; 123 / 0992 ; 171 / 1092$ & Dogs with diarrhoea & $e a e A^{+}, \mathrm{EAF}^{-}$ & This work \\
\hline $\begin{array}{l}\text { C287; C736; D20; D21; D22; D164; } \\
\text { D226; E74/68; E19895; E27688; } \\
\text { E29322 }\end{array}$ & Infant diarrhoea & $e a e A^{-}, \mathrm{EAF}^{-}$ & 21 \\
\hline D5981; D6211 & Human inflammatory bowel disease & $e a e A^{-}, \mathrm{EAF}^{-}$ & This work \\
\hline D914 & Cat with diarrhoea & $e a e A^{-}, \mathrm{EAF}^{-}$ & This work \\
\hline $\begin{array}{l}\text { C727; D103; D163; D165; D494; } \\
\text { B/M 369; C-35 }\end{array}$ & Human diarrhoea & $\mathrm{EAggEC}^{+}$ & 21 \\
\hline D895; D902 & Human diarrhoea & $\mathrm{EAggEC}^{+}$ & This work \\
\hline D64; EI314 & Human dysentery-like illness & (Enteroinvasive $E$. coli serogroups) & This work \\
\hline
\end{tabular}


were excised from gels of low melting point agarose (BRL) $1 \% \mathrm{w} / \mathrm{v}$, and labelled in situ with $\left[{ }^{32} \mathrm{P}\right]-\mathrm{dCTP}$ (ICN) with a random hexanucleotide primer labelling kit (Boehringer Mannheim). Hybridisation was done at high stringency according to the method of Sambrook et al. [29].

\section{Two-phase partitioning}

Bacteria were partitioned between two aqueous phases containing polyethylene glycol (PEG) $6000(\mathrm{BDH})$ and Dextran T-500 (Dx) (Pharmacia) [30]. PEG was made up as a stock solution of $30 \% \mathrm{w} / \mathrm{w}$ and Dextran nominally at $22 \% \mathrm{w} / \mathrm{w}$. Due to the hygroscopic nature of Dextran powder, the true concentration of the stock solution was calculated by polarimetry. Other stock solutions used were $0.6 \mathrm{M} \mathrm{NaCl}$ and $0.44 \mathrm{M}$ sodium phosphate, $\mathrm{pH} 7.4$.

Hydrophobic interactions were assayed in phase systems with three different polymer concentrations: Dx 4.5\%:PEG 4.5\%, Dx 5.5\%:PEG 5.5\% and Dx $6.5 \%:$ PEG $6.5 \%$. Surface charge differences on the transformants were assayed by incorporating sodium phosphate in Dx $4.5 \%$ :PEG $4.5 \%$ systems at $0.11 \mathrm{M}$ ('fully-charged'), $0.068 \mathrm{M}$ ('semi-charged') and $0.01 \mathrm{M}$ ('non-charged'). The phosphate distributes unequally between the two phases, resulting in the PEG phase becoming more positively charged compared to the Dextran phase, thus bacteria with a negative surface charge are attracted into the PEG. To maintain a constant ionic strength, the semi- and non-charged systems contained, respectively, $0.075 \mathrm{M}$ and $0.15 \mathrm{M} \mathrm{NaCl}$.

Phase systems were made by the addition of solutions by weight, with the salt solutions assumed to have a density of $1 \mathrm{~g} / \mathrm{ml}$, and were left overnight at $4^{\circ} \mathrm{C}$ to equilibrate. Once equilibrium was reached, the two phases of each system were separated and stored individually at $4^{\circ} \mathrm{C}$. For partition experiments, $1 \mathrm{ml}$ of an overnight culture of bacteria was pelleted by microcentrifugation and washed with $\mathrm{NaCl} 0.9 \%$ w/v. The bacteria were resuspended in an appropriate volume (generally $3-5 \mathrm{ml}$ ) of equilibrated top phase (PEG), and $1 \mathrm{ml}$ of the suspension was added to the same volume of the Dextran bottom phase in $50 \times 10$ $\mathrm{mm}$ glass tubes. The phases were mixed by repeated inversion, left for $5 \mathrm{~min}$ then mixed again. The phases were left at $4^{\circ} \mathrm{C}$ for 30 min to partition, before $0.5 \mathrm{ml}$ of each phase was carefully withdrawn and diluted with an equal volume of distilled water. The $\mathrm{OD}_{550 \mathrm{~nm}}$ of the diluted phases was measured, and bacterial partitioning calculated as the percentage of initial OD present in each phase. The difference in absorbance between the starting suspension and the sum of the two aqueous phases represented the bacteria present at the phase interface.

\section{Results}

The relatively well characterised EPEC strains K798 and E2348, along with MAR20, the EAF plasmidcured isogenic derivative of the latter, were partitioned between phases of increasing polymer concentration. Both wild-type EPEC strains partitioned solely in the top (PEG) phase regardless of polymer concentration, indicating that both had relatively high surface hydrophobicity. In contrast, when strain MAR20 was assayed, only $51 \%$ of the bacteria remained in the top phase at the lowest PEG concentration. Numbers of bacteria in the top phase decreased from $22 \%$ of the original inoculum in the PEG $5.5 \%$ concentration, to only $4 \%$ in the $6.5 \%$ system (Fig. 1). At the lowest

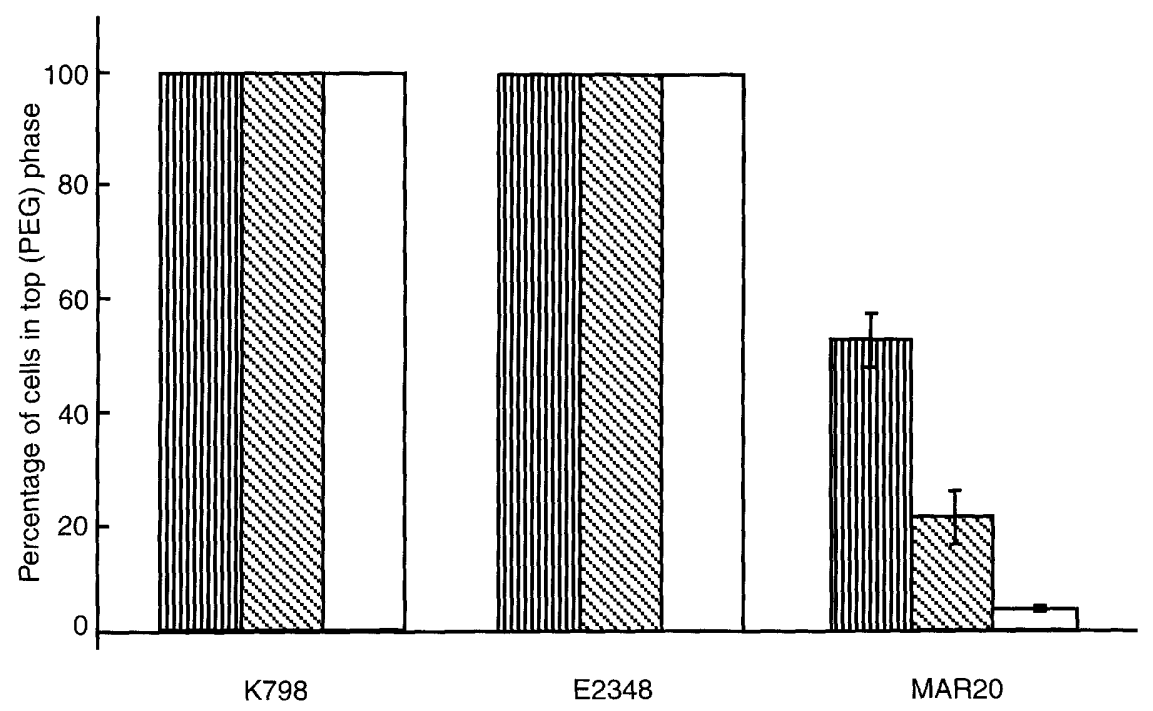

Fig. 1. Effect of increasing PEG and Dextran concentration on the partitioning of EPEC strains K798 and E2348, and the EAF plasmid-cured derivative MAR20 of E2348. Bars represent the percentage of the original bacterial suspension detected in the top (PEG) phase as determined by spectrophotometry. Assays were performed in triplicate at least twice. Error bars represent the SD for all observations on each strain. PEG 4.5\%:Dextran 4.5\%; PEG $5.5 \%$ :Dextran $5.5 \%$; $\square$ PEG $6.5 \%$ :Dextran $6.5 \%$. 
PEG concentration, the residual MAR20 cells were located at the interface, but on increasing the concentration to $5.5 \%$ and $6.5 \%$, respectively, $33 \%$ (SD 4.1) and $36 \%$ (SD 0.4) of the cells entered the bottom phase. Variations in the OD of the initial inocula, which in the majority of cases was between 0.250 and 0.4 , made no significant difference to partitioning behaviour. Riley et al. [31] have previously described a strain of EPEC of serogroup O111 that lost the lipopolysaccharide $\mathrm{O}$-antigenic side chains when cured of a 54-MDa plasmid. However, slide agglutination with 0127 -specific antiserum proved that the differences in hydrophobicity of strains E2348 and MAR20 were not due to analogous changes in $\mathrm{O}$ polysaccharide expresssion.

In view of the apparent hydrophobicity changes caused by the loss of the EAF plasmid of EPEC strain E2348, a further series of $E$. coli strains, mostly isolated from infants with diarrhoea from various geographical locations were characterised by their hybridisation to the EAF, eaeA and EAggEC DNA probes, and assayed for partitioning behaviour in the $4.5 \%$ and $5.5 \%$ polymer concentration phase systems. In the $4.5 \%$ system, those strains that did not hybridise to the EAggEC probe could be roughly divided into three groups, depending on the numbers of bacteria entering the top phase (Table 2). Strains E2348, K798 and an additional 13 strains partitioned with $>95 \%$ of the original inoculum remaining in the top phase. Of these, 12 strains were defined as EPEC on the basis of their hybridisation to the eaeA probe (including the rabbit pathogen $\mathrm{RDEC}-1$ ), with 10 also hybridising to the EAF probe. Two of the apparently eae $A^{-}$strains within this group (E27256 and E27688, both serogroup $\mathrm{O} 111$, originally isolated from outbreaks of infantile diarrhoea in the UK by the Public Health Laboratory Service), have been demonstrated to have attaching-effacing properties on rabbit ileal explants (unpublished observations). A second group of 14 strains partitioned with $65-95 \%$ of the original inoculum remaining in the top phase, and these included seven eaeA ${ }^{+}$EPEC strains, only two of which were $\mathrm{EAF}^{+}$. One of the latter (strain D46) was of interest, as we have previously demonstrated that it has both in-vitro attaching-effacing and invasive properties [21]. In the majority of these strains, the residual bacteria not remaining in the top phase were located at the phase interface. A further nine strains

Table 2. Partitioning behaviour of diarrhoeagenic $E$. coli isolates in a PEG $4.5 \%$ :Dextran $4.5 \%$ aqueous two-phase system

\begin{tabular}{lccc}
\hline $\begin{array}{l}\text { Percentage of original } \\
\text { inoculum partitioning }\end{array}$ & $\begin{array}{c}\text { Number of } \\
\text { strains }\end{array}$ & eaeA & EAF \\
\cline { 3 - 4 } in top phase & 15 & 12 & 10 \\
\hline 995 & 14 & 7 & 2 \\
$65-95$ & 9 & 4 & 0 \\
$<65$ & 9 & \\
\hline
\end{tabular}

partitioned with $<65 \%$ in the top phase, five of which failed to remain in the top phase at all. Three of the nine were of canine and one of feline origin, although the strains not remaining in the top phase were all of human origin, including one strain implicated in inflammatory bowel disease and one eae $A^{+}$EPEC strain. Statistical analysis showed that $\mathrm{EAF}^{+}$strains were significantly $(\mathrm{p}<0.05$, Student's independent $t$ test) more hydrophobic (in terms of partitioning to the top phase) than $\mathrm{EAF}^{-}$strains. Furthermore, $\mathrm{EAF}^{+}$ $e a e A^{+}$strains were significantly more hydrophobic than $\mathrm{EAF}^{-} e a e A^{+}$strains $(\mathrm{p}<0.05)$.

Increasing the polymer concentration in the phase systems led to a reduction in the top phase partitioning of many of the strains. Of those that partitioned completely in this phase at PEG $4.5 \%$, two eae $A^{+}$strains had slightly decreased partitioning (75\% and $86 \%$ ) at the higher concentration, and a further two, both of serogroup O142, were affected to a greater extent, remaining in the top phase to $48 \%$ and $34 \%$ of the original cell suspension (Table 3 ). The $e a e A^{+} \mathrm{EAF}^{+}$strains that had partitioned at $65-95 \%$ in the top phase at PEG $4.5 \%$ were unaffected by polymer concentration changes, but three eaeA ${ }^{+}$ $\mathrm{EAF}^{-}$and five eae $A^{-}$strains had markedly decreased top phase partitioning activity. Two enteroinvasive $E$. coli strains also failed to remain in the top phase at either polymer concentration (data not shown).

In contrast to the EPEC strains, those hybridising with the EAggEC probe showed highly disparate partitioning behaviour; three strains were predominantly in the top phase, four did not remain in this phase at all, but some entered the bottom phase, and two were intermediate in partitioning behaviour (Fig. 2). With the exception of one strain (D163) top phase partitioning was virtually eliminated in the $5.5 \%$ polymer concentration system, with most of the bacteria moving to the bottom phase (data not shown).

The results clearly indicated a correlation between carriage of EAF sequences (and thus the ability to show localised adherence to tissue culture cells) and hydrophobicity. However, previous studies found that E. coli $\mathrm{K}-12$ transformants carrying the large plasmid pLV501 from EPEC strain K798 also show localised adherence, albeit with less dense microcolonies [20]. To investigate whether the putative

Table 3. Partitioning behaviour of diarrhoeagenic $E$. coli isolates in a PEG 5.5\%:Dextran 5.5\% aqueous two-phase system

\begin{tabular}{|c|c|c|c|}
\hline \multirow{2}{*}{$\begin{array}{l}\text { Percentage of original } \\
\text { inoculum partitioning } \\
\text { in top phase }\end{array}$} & \multirow{2}{*}{$\begin{array}{c}\text { Number of } \\
\text { strains }\end{array}$} & \multicolumn{2}{|c|}{ Number hybridising with } \\
\hline & & eaeA & EAF \\
\hline$>95$ & 11 & 8 & 6 \\
\hline $65-95$ & 8 & 6 & 4 \\
\hline$<65$ & 19 & 9 & 2 \\
\hline
\end{tabular}




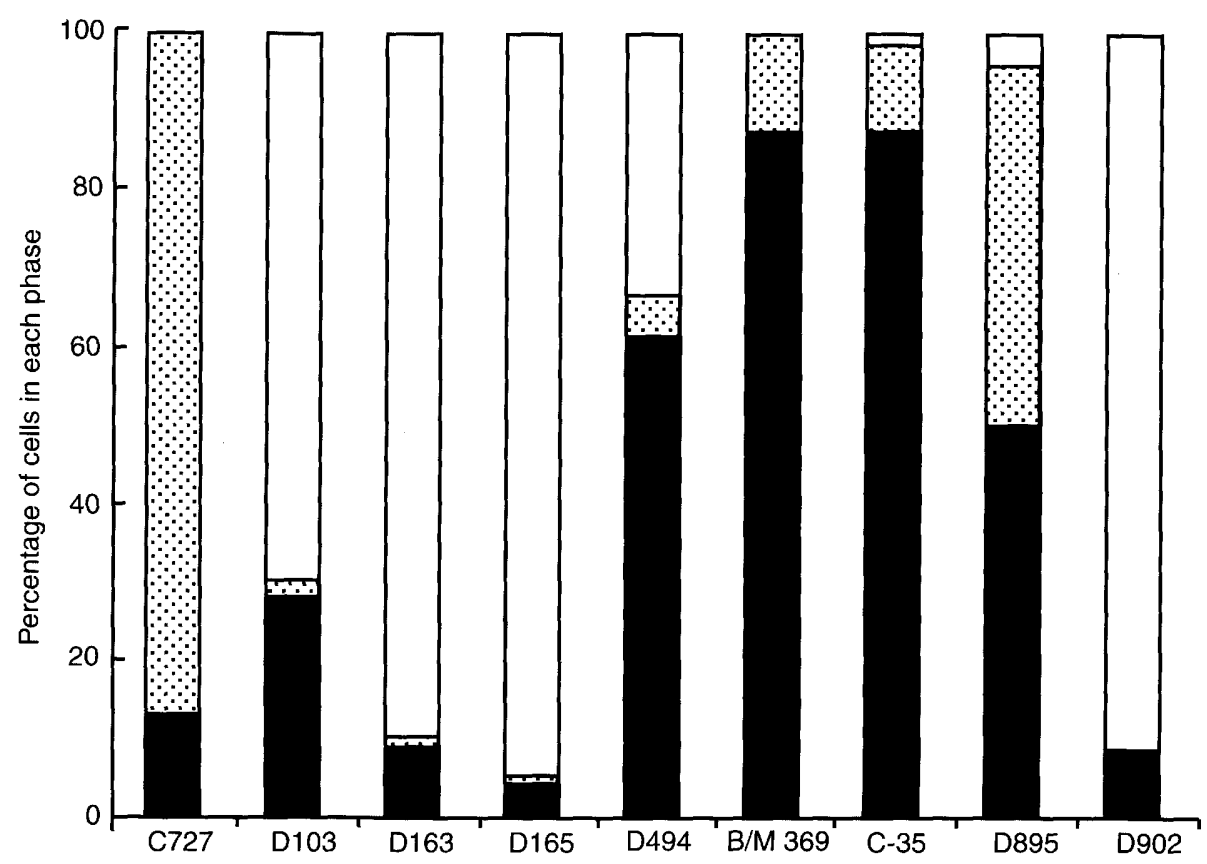

Fig. 2. Partitioning behaviour of nine E. coli strains hybridising with the EAggEC probe in a PEG 4.5\%:Dextran $4.5 \%$ uncharged phase system. The proportion of the original cell suspension partitioning in each phase is shown: percentage in bottom (Dextran) phase; percentage at interface of phases: $\square$ percentage in top (PEG) phase.

non-EAF-associated adhesins involved caused changes in the surface hydrophobicity, E. coli DH1 transformants carrying pLV501, pLV527 (a plasmid that encodes diffuse adhesive and invasive properties) and pLV526 (a pLV501-derived recombinant plasmid that does not specify adhesion) were partitioned in the non-charged system. Whereas strain K798 partitioned completely in the top phase at all polymer concentrations used, E. coli $\mathrm{DH} 1$ and each of the transformants partitioned mostly at the interface between the phases

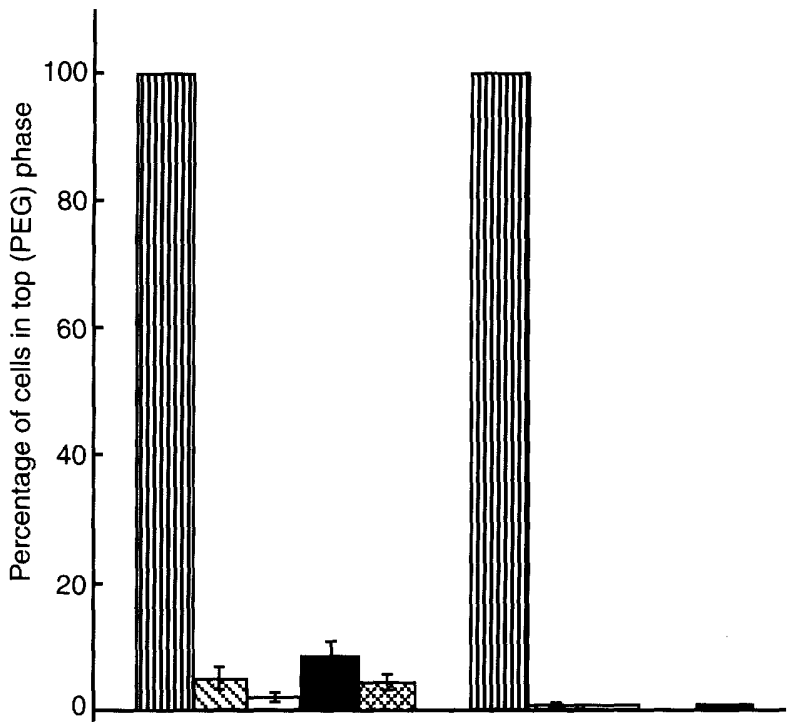

(a)

PEG 4.5\%:Dextran 4.5\% PEG 5.5\%:Dextran 5.5\% with $<9 \%$ of the bacteria in the top phase in the $4.5 \%$ polymer concentration (Fig. 3a). Increasing the polymer concentration caused $60-70 \%$ of the cells to shift to the bottom phase at both $5.5 \%$ and $6.5 \%$ PEG and Dextran, with no differences between transformed and non-transformed DH1. The surface charge characteristics of the transformants were evident with charged phase systems. K798 partitioning was unaffected by an increase in the sodium phosphate concentrations, but both $\mathrm{DH} 1$ and the transformants were shifted back to

Fig. 3. Partitioning behaviour of EPEC strain K798, E. coli K-12 strain DH1 and EPEC plasmid-derived DH1 transformants: K798; DH1; $\square$ DH1(pLV501); DH1(pLV527); DH1(pLV526). a, non-charged (0.01 M sodium phosphate) phase systems of increasing polymer concentration; $\mathbf{b}$, increasing charge in a PEG $4.5 \%:$ Dextran $4.5 \%$ phase system.

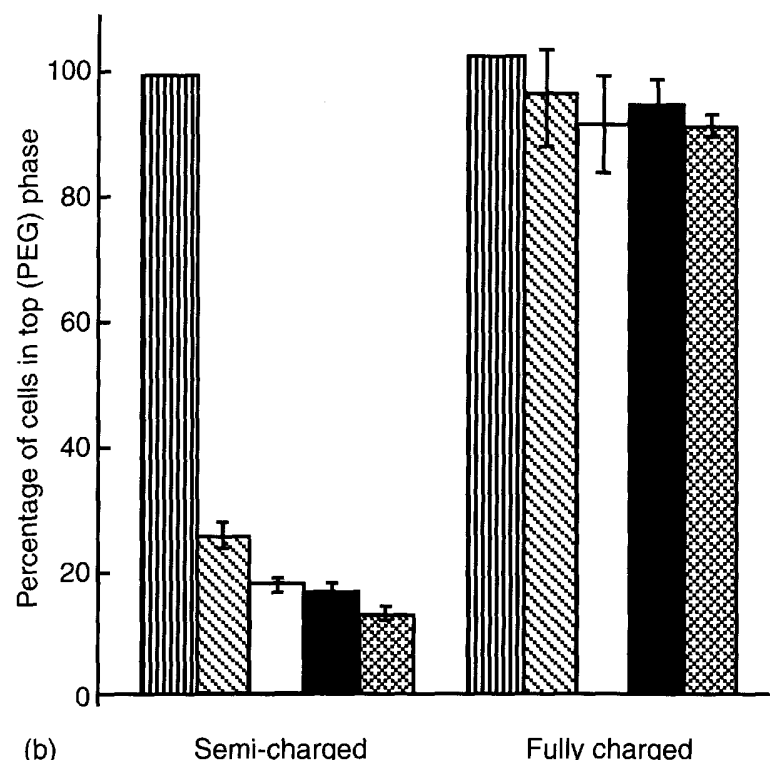


the top phase (Fig. 3b), indicating that in these organisms, a surface negative charge has more influence on partitioning than their relatively low hydrophobicity.

Partitioning of EPEC strain E2348 was also unaffected by changes in the phosphate concentration. However, the EAF plasmid-cured derivative MAR20 behaved similarly to the $\mathrm{K}-12$ strain $\mathrm{DH} 1$, with an increase in phosphate concentration causing an increase in numbers of cells in the top phase (Fig. 4).

\section{Discussion}

Aqueous two-phase partitioning has previously proved to be a useful technique for investigating the properties of surface hydrophobicity and charge of a number of micro-organisms. Unfortunately, the parameters involved in partitioning bacteria on the basis of hydrophobicity alone are poorly understood. It is believed that for each bacterial strain there is a critical polymer concentration, below which the bacteria partition in one of the bulk phases and above which the bacteria are confined to the interface. This critical polymer concentration increases with higher surface hydrophobicity [32]. Theoretically, therefore, bacterial partitioning behaviour should involve only one of the two bulk phases and the interface between them. In general terms, this holds true for most of the EPEC strains described here, although two strains partitioned between both bulk phases, which may be a result of non-heterogeneous populations as regards expression of hydrophobic surface determinants.

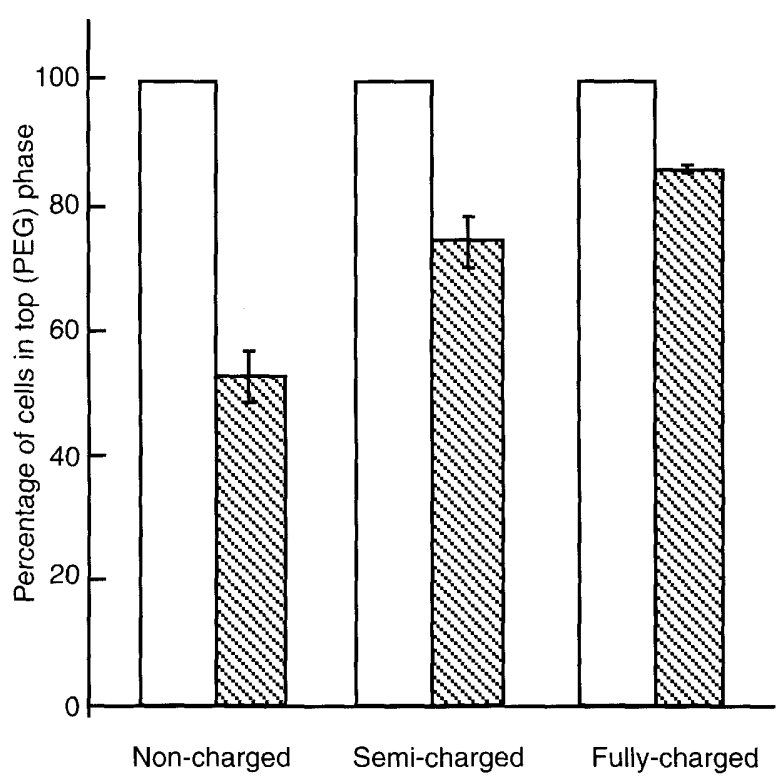

Fig. 4. Comparison of the partitioning behaviour of EPEC strain E2348 ( $\square$ ) and the EAF plasmid-cured derivative MAR20 in PEG $4.5: \%$ Dextran $4.5 \%$ phase systems of increasing charge. Sodium phosphate concentrations in each were: non-charged, $0.01 \mathrm{M}$; semicharged, $0.068 \mathrm{M}$; fully-charged, $0.11 \mathrm{M}$.
For several micro-organisms, e.g., Shigella spp. [33], enterotoxigenic E. coli [34] and Yersinia enterocolitica [8], surface hydrophobicity is positively correlated with carriage of virulence plasmids. Qualitative observations such as colony morphology and autoaggregation in liquid culture suggest that many EPEC strains are relatively hydrophobic, and partitioning assays on the well characterised strains K798 and E2348 confirm this. The present study demonstrated that MAR20, the EAF plasmid-cured derivative of EPEC strain E2348, has greatly decreased surface hydrophobicity compared to its parent, in that its critical polymer concentration is $<4.5 \%$ for PEG and Dextran, whereas E2348 has a critical polymer concentration $>6.5 \%$. Therefore, it may have been predicted that class I EPEC strains that naturally carry EAF plasmids would be relatively more hydrophobic than the class II strains which lack them. The results support this hypothesis, with most $\mathrm{EAF}^{+}$isolates having a higher critical polymer concentration than EAF $^{-}$strains. Thus, it would appear that one or more surface exposed proteins or structures encoded on the EAF plasmid makes a significant contribution to the overall surface hydrophobicity. The obvious candidate is the inducible bundle-forming pilus, the major subunit of which is encoded by the $b f p A$ gene [14]. The link between carriage of the EAF plasmid and hydrophobicity is not absolute, as two eaeA ${ }^{+} \mathrm{EAF}^{-}$ strains were among the most hydrophobic of those tested. However, the EAF probe does not detect the $b f p A$ gene, and in one survey has been shown to be only $96 \%$ sensitive for detecting strains showing localised adherence [15]. Therefore, it is possible that certain strains do not hybridise to the EAF probe but do express bundle-forming pili that contribute to the surface hydrophobicity. Similarly, the rabbit pathogen RDEC-1, although analogous to human EPEC strains in possessing the eaeA gene, does not carry an EAF plasmid, or the $b f p A$ gene, but is very hydrophobic. However, it does express an alternative fimbrial structure, AF/R1 [25]. Although RDEC-1 does not manifest the localised adherence phenotype, and $\mathrm{AF} /$ $\mathrm{R} 1$ is not critical in the pathogenesis of the disease, the fimbriae do serve to promote the initial adherence of RDEC-1 to the brush border [35].

Conversely, there are two $\mathrm{EAF}^{+}$EPEC strains which are notable in having distinctly lower hydrophobicity (partitioning at $69 \%$ and $75 \%$ in the top phase in the lowest polymer concentration). One of these, the nonserogroupable strain D46, is of particular interest, as it possesses invasive as well as attaching-effacing characteristics [21]. It has not been determined whether the $b f p A$ gene is present in these strains or, if so, whether pilus assembly and expression are induced correctly. The possible lack of O-polysaccharide side chains may also contribute to the lower hydrophobicity: the rough $E$. coli $\mathrm{K}-12$ strain $\mathrm{DH} 1$ has very low hydrophobicity. More intriguingly, Riley et al. [31] described an EPEC strain that, when cured of 
a 54-MDa plasmid, lost the O-polysaccharide side chains and became invasive. The low hydrophobicity of the two enteroinvasive strains tested here may indicate that invasive behaviour is either supported by lower hydrophobicity or inhibited by high surface hydrophobicity.

Enteroaggregative E. coli (EAggEC) strains also produce specific plasmid-encoded fimbriae, termed $\mathrm{AAF} / \mathrm{I}$, which are responsible for adherence to tissue culture cells and autoagglutination in broth cultures [36]. By analogy with the bundle-forming pili of $\mathrm{EAF}^{+}$EPEC and AF/R1 of RDEC-1, it would be predicted that EAggEC strains should be relatively hydrophobic. Whilst this was true for some of the strains tested, others were much less hydrophobic. Members of this class of E. coli partitioned into the lower phase of the systems much more readily than the EPEC strains. Other fimbriae co-expressed with AAF/I have been identified in some EAggEC strains [37], and there is the possibility of a synergic effect, or a greater contribution of surface charge, to account for the partitioning behaviour.

McConnell [38] has identified new adhesins in enterotoxigenic $E$ coli by an increase in hydrophobicity, and the expression in some $E$. coli strains of the novel filamentous surface appendages termed curli also causes an increase in surface hydrophobicity [39]. Transformant DH1(pLV501) shows a form of localised adherence to tissue culture cells in the absence of the EAF plasmid, a process which presumably involves a novel adhesin. However, in this case, no difference can be detected in the behaviour of $\mathrm{DH} 1$ with and without pLV501. Strain DH1 has a very low surface hydrophobicity, and its partitioning in the systems used appears to be on the basis of surface charge alone. The use for adhesion assays of a transformant host strain that has such different hydrophobic properties from the pathogenic strains it is modelling is problematical, as it has been suggested that hydrophobic interactions may serve to promote initial association of the bacteria with the mucosal surface before shorter range specific adhesins can act [2]. In mitigation, most pathogenic bacteria are weakly negatively charged; in the case of most EPEC strains this charge is not measurable because of the dominating hydrophobic effects.

This work was funded by grants from the Wellcome Trust. We are grateful to $\mathrm{Dr} \mathrm{D}$. Fisher for valued advice regarding phase partitioning techniques.

\section{References}

1. Wanke CA, Guerrant RL. Small-bowel colonization alone is a cause of diarrhea. Infect Immun 1987; 55: 1924-1926.

2. Beachey EH. Bacterial adherence: adhesin-receptor interactions mediating the attachment of bacteria to mucosal surfaces. $J$ Infect Dis 1981; 143: 325-345.

3. van Loosdrecht MCM, Lyklema J, Norde W, Schraa G,
Zehnder AJB. The role of bacterial cell wall hydrophobicity in adhesion. Appl Environ Microbiol 1987; 53: 1893-1897.

4. Magnusson K-E, Davies J, Gundström T, Kihlström E, Normark S. Surface charge and hydrophobicity of Salmonella, E. coli, gonococci in relation to their tendency to associate with animal cells. Scand J Infect Dis 1980; Supplement 24: $135-140$.

5. Wibawan IWT, Lämmler C, Pasiribu FH. Role of hydrophobic surface proteins in mediating adherence of group B streptococci to epithelial cells. J Gen Microbiol 1992; 138: $1237-$ 1242.

6. John SF, Hillier VF, Handley PS, Derrick MR. Adhesion of staphylococci to polyurethane and hydrogel-coated polyurethane catheters assayed by an improved radiolabelling technique. J Med Microbiol 1995; 43: 133-40.

7. Qadri F, Hossain SA, Ciznár I et al. Congo red binding and salt aggregation as indicators of virulence in Shigella species. $J$ Clin Microbiol 1988; 26: 1343-1348.

8. Pærregaard A, Espersen F, Baker N. The influence of properties encoded by the Yersinia virulence plasmid on adhesion of Yersinia enterocolitica to ileal brush border membrane vesicles. APMIS 1990; 98: 927-932.

9. Tertti R, Skurnik M, Vartio T, Kuusela P. Adhesion protein YadA of Yersinia species mediates binding of bacteria to fibronectin. Infect Immun 1992; 60: 3021-3024.

10. Rothbaum R, McAdams AJ, Giannella R, Partin JC. A clinicopathologic study of the enterocyte-adherent Escherichia coli: a cause of protracted diarrhea in infants. Gastroenterology 1982; 83: $441-454$

11. Donnenberg MS, Kaper JB. Enteropathogenic Escherichia coli. Infect Immun 1992; 60: 3953-3961.

12. Baldini MM, Kaper JB, Levine MM, Candy DCA, Moon HW, Plasmid-mediated adhesion in enteropathogenic Escherichia coli. J Pediatr Gastroenterol Nutr 1983; 2: 534-538.

13. Nataro JP, Scaletsky ICA, Kaper JB, Levine MM, Trabulsi LR Plasmid mediated factors conferring diffuse and localized adherence of enteropathogenic Escherichia coli. Infect Immun 1985; 48: $378-383$.

14. Donnenberg MS, Girón JA, Nataro JP, Kaper JB. A plasmidencoded type IV fimbrial gene of enteropathogenic Escherichia coli associated with localized adherence. Mol Microbiol 1992; 6: $3427-3437$.

15. Girón JA, Donnenberg MS, Martin WC, Jarvis KG, Kaper JB. Distribution of the bundle-forming pilus structural gene $(b f p A)$ among enteropathogenic Escherichia coli. J Infect Dis 1993; 168: 1037-1041.

16. Jerse AE, Kaper JB. The eae gene of enteropathogenic Escherichia coli encodes a 94-kilodalton membrane protein, the expression of which is influenced by the EAF plasmid. Infect Immun 1991; 59: 4302-4309.

17. Donnenberg MS, Tacket CO, James SP et al. Role of the eaeA gene in experimental enteropathogenic Escherichia coli infection. J Clin Invest 1993; 92: 1412-1417.

18. Levine MM, Nataro JP, Karch $\mathrm{H}$ et al. The diarrheal response of humans to some classic serotypes of enteropathogenic Escherichia coli is dependent on a plasmid encoding an enteroadhesiveness factor. J Infect Dis 1985; 152: 550-559.

19. Nataro JP, Baldini MM, Kaper JB, Black RE, Bravo N, Levine MM. Detection of an adherence factor of enteropathogenic Escherichia coli with a DNA probe. J Infect Dis 1985; 152: $560-565$.

20. Fletcher JN, Saunders JR, Batt RM, Embaye H, Getty B, Hart CA. Attaching effacement of the rabbit enterocyte brush border is encoded on a single 96.5-kilobase-pair plasmid in an enteropathogenic Escherichia coli 0111 strain. Infect Immun 1990; 58: 1316-1322.

21. Fletcher JN, Embaye HE, Getty B, Batt RM, Hart CA, Saunders JR. Novel invasion determinant of enteropathogenic Escherichia coli plasmid pLV501 encodes the ability to invade intestinal epithelial cells and HEp-2 cells. Infect Immun 1992; 60: $2229-2236$

22. Levine MM, Bergquist EJ, Nalin DR et al. Escherichia coli strains that cause diarrhoea but do not produce heat-labile or heat-stable enterotoxins and are non-invasive. Lancet 1978; 1: $1119-1122$.

23. Donnenberg MS, Donohue-Rolfe A, Keusch GT. Epithelial cell invasion: an overlooked property of enteropathogenic Escherichia coli (EPEC) associated with the EPEC adherence factor. Infect Dis 1989; 160: 452-459. 
24. Tzipori S, Gibson R, Montanaro J. Nature and distribution of mucosal lesions associated with enteropathogenic and enterohemorrhagic Escherichia coli in piglets and the role of plasmid-mediated factors. Infect Immun 1989; 57: 1142-1150.

25. Cheney CP, Formal SB, Schad PA, Boedeker EC. Genetic transfer of a mucosal adherence factor (R1) from an enteropathogenic Escherichia coli strain into a Shigella flexneri strain and phenotypic suppression of this adherence factor. $J$ Infect Dis 1983; 147: 711-723.

26. Baldini MM, Nataro JP, Kaper JB. Localization of a determinant for HEp-2 adherence by enteropathogenic Escherichia coli. Infect Immun 1986; 52: 334-336.

27. Jerse AE, Gicquelais KG, Kaper JB. Plasmid and chromosomal elements involved in the pathogenesis of attaching and effacing Escherichia coli. Infect Immun 1991; 59: 3869-3875.

28. Baudry B, Savarino SJ, Vial P, Kaper JB, Levine MM. A sensitive and specific DNA probe to identify enteroaggregative Escherichia coli, a recently discovered diarrheal pathogen. $J$ Infect Dis 1990; 161: 1249-1251.

29. Sambrook J, Fritsch EF, Maniatis T. Molecular cloning: a laboratory manual, 2nd edn. Cold Spring Harbor, NY, Cold Spring Harbor Laboratory Press. 1989.

30. Magnusson K-E. The hydrophobic effect and how it can be measured with relevance for cell-cell interations. Scand $J$ Infect Dis 1980; Supplement 24: 131-134.

31. Riley LW, Junio LN, Schoolnik GK. HeLa cell invasion by a strain of enteropathogenic Escherichia coli that lacks the Oantigenic polysaccharide. Mol Microbiol 1990; 4: 1661-1666.

32. Fisher D. Separation and subfractionation of cell populations by phase partitioning - an overview. In: Fisher D, Sutherland IA (eds) Separations using aqueous phase systems. Applications in cell biology and biotechnology. New York, Plenum Press. 1989. 119-125
33. Pál T, Lindberg AA. Association of invasive Shigella strains with epithelial cells. In: Wadström T, Mäkelä PH, Svennerholm A-M, Wolf-Watz $\mathrm{H}$ (eds) Molecular pathogenesis of gastrointestinal infections. New York, Plenum Press. 1991: 223-229.

34. Wadström T, Farris A, Freer J, Habte D, Hallberg D, Ljungh A. Hydrophobic surface properties of enterotoxigenic $E$. coli (ETEC) with different colonization factors (CFA/I, CFA/II, K88 and K99) and attachment to intestinal epithelial cells. Scand $J$ Infect Dis 1980; Supplement 24: 148-153.

35. Wolf MK, Andrews GP, Fritz DL, Sjogren RW, Boedeker EC Characterization of the plasmid from Escherichia coli RDEC-1 that mediates expression of adhesin AF/R1 and evidence that AF/R1 pili promote but are not essential for enteropathogenic disease. Infect Immun 1988; 56: 1846-1857.

36. Nataro JP, Deng Y, Maneval DR, German AL, Martin WC, Levine MM. Aggregative adherence fimbriae I of enteroaggregative Escherichia coli mediate adherence to HEp-2 cells and hemagglutination of human erythrocytes. Infect Immun 1992; 60: 2297-2304

37. Knutton S, Shaw RK, Bhan MK et al. Ability of enteroaggregative Escherichia coli strains to adhere in vitro to human intestinal mucosa. Infect Immun 1992; 60: 2083-2091.

38. McConnell MM. Newly characterized putative colonization factors of human enterotoxigenic Escherichia coli. In: Wadström T, Mäkelä PH, Svennerholm A-M, Wolf-Watz $\mathrm{H}$ (eds) Molecular pathogenesis of gastrointestinal infections. New York, Plenum Press. 1991: 79-85.

39. Emödy L, Ljungh $\AA$, Pal T, Sarlós G, Wadström T. Expression and possible biological functions of curli on infantile diarrhoea Escherichia coli isolates. In: Wadström $\mathrm{T}$, Mäkelä $\mathrm{PH}$, Svennerholm A-M, Wolf-Watz H (eds) Molecular pathogenesis of gastrointestinal infections. New York, Plenum Press. 1991: 303-306. 